Izvorni članak UDK 1(045) Petrić, F. doi: 10.21464/fi39304 Primljeno: 9. 9. 2019.

\title{
Ćiril Čoh
}

Ulica Široke ledine 14, HR-42000 Varaždin ciril.coh1@vz.t-com.hr

\section{Petrićev zagonetni govor kroz ustroj Peripatetičkih rasprava}

\begin{abstract}
Sažetak
Članak polazi od pretpostavke da je u Petrićevoj filozofiji sveukupnost analogna filozofiji cjelokupnosti (philosophia universi), odnosno djelu koje ju izlaže. Sve što u sveukupnosti nastaje ima svoje umještanje, chora. Isto tako, u filozofskom djelu sve izloženo mora biti izloženo na svom mjestu. Petrićevo djelo Peripatetičke rasprave promišljeno je ustrojeno brojem svojih dijelova i odnosima među njima. Nije slučajan broj svezaka, broj knjiga u svakome od njih, a ni broj folija u svakom pojedinom svesku. Sve to upućuje na ustroj djela prema Platonovoj crti. Svrha djela je procjena (censura) Aristotelove filozofije spram istinske filozofije, filozofije Platona i prethodnika, njihova učenja o prvim počelima, a prije svega Platonova nepisanog učenja o velikom $i$ malom te jednom. Govor o tome kod istinskih filozofa ne može biti u svemu izravan, nego mora biti zagonetan u onom bitnom.
\end{abstract}

\section{Ključne riječi}

Frane Petrić, Peripatetičke rasprave, nepisano učenje, Platonova crta, Platon, Aristotel, govor, veliko i malo, materija, umještanje, chora

\section{Uvod}

Peripatetičke rasprave (Discussionum Peripateticarum, tomi IV) Frane Petrića ${ }^{1}$ vješto i učeno objašnjavaju, kako to kaže autor u njihovoj najavi, cjelokupnu povijest i učenje Aristotelove filozofije uspoređenu s mišljenjima starih. ${ }^{2}$ Ta uspoređenost nije faktografska nego filozofska. Ona treba dovesti do ocjene (censura) Aristotelove filozofije spram istinske filozofije Platona i starih. Sve to podrazumijeva inteligibilnu razdiobu na dijelove, uspostavu odnosa među njima i s cjelinom. Zbog toga su Peripatetičke rasprave promišljeno ustrojene. Broj svezaka nije slučajan, isto tako ni broj knjiga u svakome od njih, a ni broj folija u svakom pojedinom svesku i u cjelini djela.

U našem radu polazimo od pretpostavke da je kod Petrića cjelina svega, sveukupnost, analogna filozofiji cjelokupnosti (philosophia universi), odnosno djelu koje ju izlaže. Ta pretpostavka podjednako vrijedi za Novu sveopću filozofiju (Nova de universis philosophia), ${ }^{3}$ kao i za Peripatetičke rasprave.

1

Usp. Franciscus Patricius, Discussiones Peripateticae, Böhlau Verlag, Köln, Weimar, Beč 1999.

2

Usp. Frane Petrić, Peripatetičke rasprave, sv. 3, preveli Tomislav Ćepulić, Mihaela Girardi-
Karšulin, Institut za filozofiju, Zagreb 2009., str. 277.

3

Usp. Frane Petrić, Nova sveopća filozofija, preveli Tomislav Ladan, Serafin Hrkać, Sveučilišna naklada Liber, Zagreb 1979. 
Sve što u sveukupnosti nastaje ima svoje umještanje, chora (Tim. 52a8-b2). ${ }^{4}$ Isto tako, sve što je izloženo u filozofskom djelu mora biti izloženo na svom mjestu. Jedna od Petrićevih kritika Aristotelove filozofije jest i u tome da on taj zahtjev ne poštuje. Tako, primjerice, Petrić kaže da Aristotel o prvim počelima ne raspravlja »na pravom, na vlastitom mjestu (proprio suo loco)«, kad o njima raspravlja u dvije knjige Fizike. ${ }^{5}$ Isto tako, kaže da je Aristotel pisao bez reda pa da je zato on sredio sve što je Aristotel htio reći. ${ }^{6}$ Nadalje, Aristotel nema istinski pojam o samoj umještenosti (chora) ${ }^{7}$ u kojoj treba gledati sveukupnost, o odnosima unutar članova slijeda dimenzija (točka, dužina, površina, volumen) ${ }^{8}$ o šest smjerova neba (dolje i gore, lijevo i desno, naprijed i natrag), ${ }^{9}$ o idejama koje su, kako ćemo pokazati, usko povezane s idejom umještanja.

U kratkom prikazu sadržaja na početku djela Petrić kaže da se u prvom svesku raspravlja o Aristotelovu životu, običajima, knjigama, slušateljima, sljedbenicima, izlagačima, tumačima, sljedbama i o načinu filozofiranja. Drugi svezak sadrži slaganje (concordia) Aristotela s Platonom i prethodnicima u pojedinim rodovima filozofije. Treći svezak je po svom sadržaju kontraran drugome. U njemu se izlaže Aristotelovo neslaganje (discordia) s Platonom i prethodnicima. U četvrtom svesku daje se ocjena (censura) Aristotelovih učenja. Petrić također navodi koliko knjiga ima pojedini svezak. Tako kaže da prvi svezak svoju građu raspravlja u trinaest knjiga, da drugi sadrži osam knjiga, da nakon toga u trećem svesku slijedi sedam knjiga i da se filozofska ocjena Aristotelovih učenja izlaže u deset knjiga.

U odnosima sadržaja pojedinih svezaka posebno je upadljiv odnos sadržaja drugoga i trećega. Radi se o svojevrsnoj kontrarnosti slaganja i neslaganja. Aristotelovo slaganje s Platonom i prethodnicima nije neko istinsko slaganje nego vanjsko. Ono najčešće proizlazi iz toga što je Aristotel, prema Petrićevu mišljenju, mnogo toga preuzeo ili ukrao od Platona i starih filozofa. U pravom smislu slaganja s Platonom i prethodnicima ovdje nema. To je lažno slaganje. Međutim, neslaganje Aristotela s Platonom, koje se prikazuje u trećem svesku, istinito je. Drugim riječima, u trećem svesku ima više istine nego u drugom. Dalje bi se moglo reći da u drugom svesku ima više istine nego u prvom. U tom slijedu od prvog do četvrtog sveska prepoznajemo stupnjevanje sadržaja prema istinitosti, ono isto koje Platon razlaže na crti u šestoj knjizi Politeje (Resp. 510a).

Platonovu crtu prepoznajemo i u odnosima sadržaja prvog i drugog sveska, kao jedne cjeline, spram sadržaja trećeg i četvrtog, kao druge cjeline. Tu prepoznajemo analogiju s odnosom osjetivog i umljivog. U prva dva sveska istražuje se ono što mogu istražiti i oni koji istinski ne filozofiraju, a u druga dva ono što je moguće istražiti samo istinskim filozofima. Ne može svatko staviti Aristotela u odnos spram filozofije Platona i njegovih prethodnika. Ne može svatko procijeniti Aristotelovu filozofiju prema mjeri onog što Platon zove istinska filozofija, alethine philosophia (Resp. 521c8). ${ }^{10}$

Presudni značaj za našu raspravu ima postava odnosa sadržaja trećeg i četvrtog sveska. Tu dolazi do bitnog odstupanja od očekivanog. Sadržaj postavljen u četvrtom odsječku - censura Aristotelove filozofije - zato što u sebi nosi više istine od trećeg, trebao bi biti kraći od njega. Međutim, Petrić nas iznenađuje. Treći je svezak kraći od četvrtoga. Treći odsječak ovdje postavljene crte na mjestu je četvrtog, a četvrti na mjestu trećeg. Jedan dio sadržaja četvrtog sveska kao da pripada trećem, što nas navodi da ga posebno izdvojimo. Pokazuje se da to ima smisla jer sadržaj koji smo četvrtom svesku oduzeli, a da bi ga trećem dodali, nije bilo koji sadržaj. U njemu se izlaže osam Aristotelovih do- 
kazivanja prvih počela. Taj dio teksta traži odnos s osam slaganja s Platonovim učenjem iz drugog sveska (odsječka) i sedam neslaganja iz trećeg sveska (odsječka). Unutar četvrtog sveska uspostavlja se, dakle, novi peti odsječak. Ustrojem svoga djela Petrić nas navodi da Platonovu crtu dijelimo dalje od četvrtog odsječka, sve do šestog. Njegovim uspostavljanjem dolazimo do srži Peripatetičkih rasprava, a time do konačne censure Aristotelove filozofije.

\section{Ustroj Peripatetičkih rasprava prema broju knjiga i broju folija u pojedinim dijelovima}

Pojedini svesci Peripatetičkih rasprava svojim sadržajima upućuju na Platonovu crtu. Međutim, u ustroju Peripatetičkih rasprava prepoznajemo još jedno takvo, u sebi dvostruko upućivanje. Pojedini svesci u svom poretku upućuju na Platonovu crtu i brojem odnosno dužinom. Ta dužina određena je na dva načina: brojem knjiga i brojem folija. ${ }^{11}$ Prvi svezak ima trinaest knjiga na 174 folije, drugi osam na 112 folija, treći sedam na 74 folije i četvrti deset na 119 folija. Ukupno je to trideset osam knjiga na 479 folija.

Razmotrimo najprije podjelu prema broju knjiga. Njihov ukupan broj (38) sastavljen je od brojeva 23 i 15. Broj 23 dobivamo zbrajanjem knjiga prvog i četvrtog sveska, a broj 15 zbrajanjem knjiga drugog i trećeg sveska. Sva su četiri broja članovi niza $1,7,8,15,23,38,61,99,160$. (prikaz 1, redak 1). U njemu je svaki član suma prethodnih dvaju članova, što znači da je sličan Fibonaccijevu nizu. Fibonaccijev i Petrićev niz mogu se shvatiti kao približne vrijednosti za niz brojeva uspostavljenih omjerom krajnjeg $i$ srednjeg, odnosno zlatnim rezom (prikaz 1, redak 3 ).

\begin{tabular}{|l|c|c|c|c|c|c|c|c|c|}
\hline & A & B & I. & II. & III. & IV. & V. & VI. & VII. \\
\hline Prvi Petrićev niz & 1 & 7 & 8 & 15 & 23 & 38 & 61 & 99 & 160 \\
\hline Drugi Petrićev niz & 3 & 21 & 24 & 45 & 69 & 114 & 183 & 297 & 480 \\
\hline$\Phi$ & - & - & 0,055 & 0,090 & 0,145 & 0,236 & 0,381 & 0,618 & 1 \\
\hline
\end{tabular}

Prikaz 1.

Više o raspravi o spomenutoj analogiji u Petrićevoj Novoj sveopćoj filozofiji vidi u: Ćiril Čoh, »Kompozicija 'Nove de universis philosophia' kao slika njenog sadržaja - spoznaje sveukupnosti«, u: Ljerka Schiffler (ur.), Zbornik radova VI. međunarodnog filozofskog simpozija 'Dani Frane Petrića', Cres 13.-17. srpnja 1997., Hrvatsko filozofsko društvo, Zagreb 1999., str. 227-244.

Usp. F. Petrić, Peripatetičke rasprave, sv. 3, str. 277.

Usp. Frane Petrić, Peripatetičke rasprave, sv. 4, preveli Tomislav Ćepulić, Mihaela GirardiKaršulin, Institut za filozofiju, Zagreb 2012., str. 19.

6

Usp. ibid., str. 485.
7

Usp. F. Petrić, Peripatetičke rasprave, sv. 3, str. 247-257.

Usp. ibid., str. 257.

9

Usp. F. Petrić, Peripatetičke rasprave, sv. 4, str. 533.

10

Petrić Platonovu filozofiju smatra istinskom u smislu onoga teksta iz Politeje u kojem Platon kroz takozvane tri prispodobe naznačuje što pod istinskom filozofijom misli. Ona nije »preokretanje crijepa nego preokret duše iz noćnog nekog dana u istinski«. Usp. F. Petrić, Peripatetičke rasprave, sv. 3, str. 131-133.

11

Naziv »folija rabimo za stranice originalnog izdanja, a naziv »stranica« za stranice hrvatskog dvojezičnog izdanja. 
Podjelom prema folijama uspostavlja se taj isti niz, ali tako da je svaki član u njemu utrostručen. To je niz 3, 21, 24, 45, 69, 114, 183, 297, 480 (prikaz 1, redak 2). ${ }^{12}$ Te ćemo nizove nazvati prvi Petrićev niz i drugi Petrićev niz. ${ }^{13}$ Treba odmah reći da Petrić, najvjerojatnije zbog tehničkih razloga, nije u raspodjeli folija uspio ostvariti točne brojeve (prikaz 1, redak 8). Prvi svezak nema 183 folije nego devet manje, dakle 174. Drugi svezak nema 114 folija nego dvije manje, dakle 112. Treći svezak trebao bi imati 69 folija, a ima ih 73, dakle četiri više; četvrti svezak trebao bi imati opet 114 folija, ali ima ih 119 , opet četiri više. Petrić se trudio slijediti zadane vrijednosti što je više moguće. Zato je ponegdje u numeriranju folija neke brojeve i preskočio. ${ }^{14}$

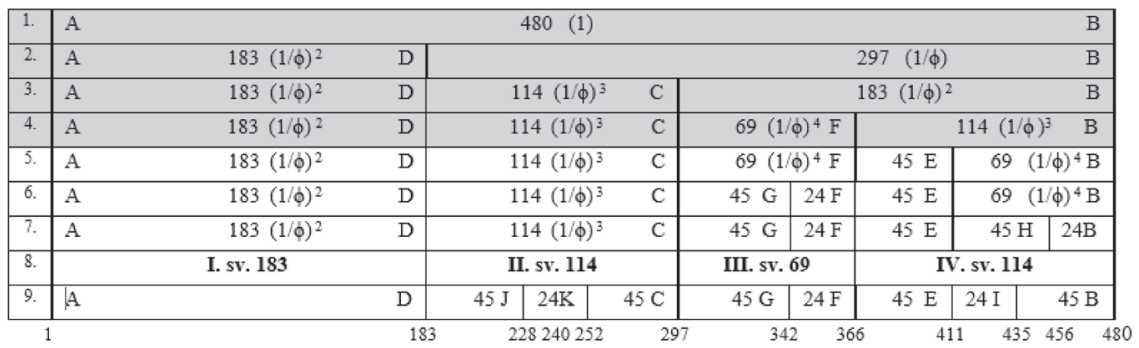

Prikaz 2.

Kod folije 297, na kraju drugog sveska, Peripatetičke rasprave dijele se po Platonovoj crti na veći (AC) i manji dio (CB). Veći odsječak zvat ćemo odsječak osjetivog, a manji odsječak umljivog. Oni se dalje dijele po istom omjeru. Kod folije 183, na kraju prvog sveska, odsječak osjetivog (AC) podijeljen je po istom omjeru na veći (AD) i manji dio (DC). Slično je podijeljen i odsječak umljivog, i to kod folije 366, s time da manji odsječak $(\mathrm{CF}, 69)$ prethodi većem (FB, 114). ${ }^{15}$ Ako manji i veći odsječak tu zamijene mjesta, nastat će nova podjela kod folije 411 (prikaz 2, redak 5). ${ }^{16}$ Njome se uspostavlja peti po redu odsječak (FE, 45). On podjednako pripada i trećem i četvrtom odsječku. Zbog toga treći odsječak može biti manji (CF, 69), a može biti i veći (CE, 114). Isto tako, četvrti odsječak može biti veći (FB, 114), a može biti i manji (EB, 69). Zadnja podjela nastaje unutar trećeg odsječka (CE, 114) kod folije 342, ako se promatra kao veći (prikaz 2, redak 6). U njegovoj sredini nastaje zadnji, šesti odsječak (GF, 24). On se pojavljuje i na kraju četvrtog odsječka (EB, 69), ako se promatra kao kraći (prikaz 2, redak 7) Tom zadnjom podjelom šesti odsječak uspostavlja se i u sredini čitave crte (JK). Njome je pozicionirana središnja folija čitavog djela, folija 240 (prikaz 2, redak 9).

Evidentno je da se u skladu s ustrojem djela crta dijeli u tri etape i da se u svakoj etapi ta podjela ostvaruje u smjeru napredovanja i vraćanja. Povezanost s pravcima kretanja u prostoru, o kojoj ćemo govoriti kasnije, daje nam za pravo da prvu etapu odredimo kao kretanje prema gore $i$ dolje, drugu kao kretanje prema naprijed $i$ natrag i treću kao kretanje u desno i lijevo. U prvoj etapi, crta se najprije, u podjeli prema gore, dijeli na veći (BD, 297) i manji dio (DA, 183), a nakon toga, u podjeli prema dolje, tako da se na crti uspostavi sredina $(\mathrm{DC}, 114)$ koja odgovara dužini drugog i četvrtog sveska (prikaz 2, redci 2 i 3). U drugoj se etapi na sličan način dijeli odsječak umljivog (CB, 183), a u trećoj etapi treći odsječak, ako se ne uzima kao manji (CF, 69), nego kao veći (CE, 114). U toj etapi događa se i podjela četvrtog odsječka, ako se uzima kao veći $(\mathrm{FB}, 114)$ i drugog odsječka (DC, 114). Zahvaljujući omjeru prema kojem je crta podijeljena, prva sredina (DC, 114) omogućuje uspostavu druge (FE, 45) i treće sredine (GF, 24; EI, 24; JK, 24). To nije bilo kakva 
sredina. Ona nije samo smještena između dva kraja jednake dužine. Ona je takva da može ući u svaki od krajeva i unutar njega formirati sredinu istih svojstava, sve do one zadnje, sržne, podjednako prisutne u svim dijelovima cjeline. Zadnja, sržna sredina 24 prisutna je i na kraju djela (prikaz 2, redak 7), ${ }^{17}$ čime i kraj postaje sredinom.

Našem bi se izlaganju mogle predbaciti barem dvije primjedbe. Prva je ta da nijedan svezak nema onoliko folija koliko bi ih po drugom Petrićevu nizu trebao imati. Ako je zaista želio upozoriti na taj niz, morao je barem u jednom od svezaka uspostaviti točan broj. Ako se nigdje ne uspostavljaju brojevi 69, $114,183,297,480$, nego samo oni koji im se približavaju, kako ćemo znati da se oni ovdje podrazumijevaju. Istina, brojevi prvog niza po kojima je određen broj knjiga pojedinog sveska pojavljuju se u točnim vrijednostima, no pitanje je može li to biti dostatan razlog za tvrdnju o prisutnosti brojeva drugog niza?

Petrić je tu primjedbu imao u vidu. Na jednom posebnom mjestu i na poseban način navodi jedan od sržnih brojeva ${ }^{18}$ svog niza. Međutim, ne čini to samo zato da bi odgovorio na našu primjedbu. U samom središtu Peripatetičkih rasprava, na foliji $235,{ }^{19}$ Petrić spominje broj $114 .{ }^{20} \mathrm{Na}$ toj foliji počinje središnja, devetnaesta po redu knjiga čitavog djela, odnosno šesta knjiga drugog

12

Omjer krajnjeg $i$ srednjeg postavljen na dužini duljine 1 je 1 : 1,618. Fibonaccijev niz je niz brojeva koji počinje brojevima 1,2 , a svaki sljedeći član zbroj je prethodnih dvaju. Tako dobivamo: $1,2,3,5,8,13,21,34,65,99$, 154 ... Između prvog i drugog člana te drugog i trećeg još nije uspostavljena približna vrijednost zlatnog reza 0,618. Prva približna vrijednost uspostavljena je tek između trećeg (5) i četvrtog člana (8). Između četvrtog (5) i petog člana vrijednost je još bliža itd. Slično vrijedi i za Petrićeve nizove: između prvog i drugog te drugog i trećeg još nije uspostavljena vrijednost zlatnog reza. Uspostavljanje te vrijednosti počinje s odnosom trećeg $\mathrm{i}$ četvrtog člana. Prikazujući točne vrijednosti, odnosno niz zlatnoreznih brojeva (prikaz 1, redak 3) uzeli smo cjelinu knjige (480 folija) kao broj 1 . Posljedično tomu, odsječak od 24 folije odgovara vrijednosti 0,055 , odsječak od 45 folija vrijednosti 0,09 , odsječak od 69 folija 0,145 itd.

13

Sličan niz nailazimo u Petrićevu glavnom djelu Nova sveopća filozofija. Ono je također ustrojeno po Platonovoj crti i to brojevima koji su povezani s brojevima prvog Petrićeva niza. Niz koji je u ustroju Nove sveopće filozofije ne počinje s brojevima $1,7,8$, nego s brojevima 1, 4, 5. To je niz: $1,4,5,9,14$, 23, 37, 60, 97, 156. Zbog drugačijeg početka $(1,4,5 \ldots$ umjesto $1,7,8 \ldots)$ on ne završava brojem 160 nego brojem 156. Usp. Ć. Čoh, »Kompozicija 'Nova de universis philosophia'«.

14

Tako su između drugog i trećeg sveska u numeriranju preskočeni brojevi: 283, 284, 285, 286.
15

Zbog veće preglednosti pored oznake za pojedini odsječak unutar crte, kad je potrebno navodimo i broj kojim je određena dužina odsječka.

16

Na prikazu 2 prikazano je postupno dijeljenje crte, od podjele na dva dijela (redak 2), u kojoj se uspostavljaju dvije veličine (297 i 183) do podjele na sedam dijelova (redak 7), u kojem se uspostavljaju daljnje veličine $(114,69$, 45 i 24). Uz svaku tu vrijednost navedena je i vrijednost prema omjeru krajnjeg $i$ srednjeg.

17

Ako se četvrti odsječak ne uzima kao veći (FB, 114), nego kao manji (EB, 69), na njegov kraj pada odsječak (HB, 24). To se događa ako se treći odsječak uzima kao veći (CE, 114).

18

Sržni brojevi su brojevi koji se odnose na jednu od triju sredina. Prvi od njih (114) omogućuje preostala dva (45 i 24).

19

To je jako blizu točnom središtu Peripatetičkih rasprava. Ono se, kako smo već rekli, nalazi na foliji 240 .

20

Upućivanje na prvi sržni broj, na broj 114 , događa se u svesku koji ima 114 folija. Gledano na crti, taj svezak predstavlja središnji odsječak čitavog djela. Petrić ističe broj 114 u središtu tog središta, u središtu koje je određeno trećim sržnim brojem, brojem 24 . 
sveska. Neuobičajeno je da autor zasebni dio svoga djela počinje rečenicom čije su prve riječi jedan, na prvi pogled, običan broj. Petrić, ovdje, u središtu svoga djela, određenom ne samo prema broju knjiga nego i prema folijama, čini upravo to. Osvrćući se na sadržaj prethodne, pete knjige, Petrić započinje ovim riječima:

»Stotinu smo i 14 mjestā iz Aristotelovih knjiga naveli u prethodnoj knjizi.« ${ }^{21}$

Nije ovdje izrečen neki okrugli ili simbolički broj, ${ }^{22}$ nego broj koji, barem se tako čini, precizno određuje koliko je Aristotelovih citata u prethodnoj knjizi Petrić upotrijebio. Poziva nas da te citate prebrojimo. ${ }^{23}$ Poslušamo li ga, naći ćemo se pred zagonetkom i uskoro shvatiti da je to upravo ta zagonetka kojom se već bavimo. Tih citata nema 114 nego 99. Tako posebno najavljena jedna precizna vrijednost, a ostvarena s tako velikim odstupanjem! Petrić vjerojatno hoće skrenuti pozornost ne samo na broj 114 nego i na broj 99. Taj broj član je prvog niza i odgovara broju $297 \mathrm{iz} \mathrm{drugog} \mathrm{niza.}{ }^{24}$ To nije slučajno. Upućivanje je to na početnu podjelu crte, na podjelu prema dolje i gore. Podjelom prema dolje (prikaz 2, redak 2) nastaju prvi odsječak (BD, 297) i drugi odsječak (DA, 183). Podjelom prema gore (prikaz 2, redak 3 ) ti odsječci u sredini crte oblikuju treći odsječak (DC, 114), upravo taj na koji Petrić zagonetno upućuje.

Druga primjedba odnosi se na numeraciju zadnje folije. Knjiga završava folijom 479 umjesto 480. Ta je primjedba ozbiljnija od prve. Možemo Petriću oprostiti što nije zbog tehničkih poteškoća uspio postaviti točne vrijednosti brojeva prvog niza u broju folija, međutim, u numeriranju zadnjih folija takvih problema ne bi trebao imati. Kad je u numeriranju folija trećeg sveska preskočio četiri broja mogao je preskočiti još jedan. Tako bi barem broj na zadnjoj foliji odgovarao onom koji je zadan drugim nizom. A što ako je Petrić imao poseban razlog odstupiti od tog broja i to upravo za 1? Nešto slično učinio je i u Novoj sveopćoj filozofiji. To djelo nema 156 folija nego 153, tri manje od broja koji je nizom 1, 4, 5, 9, 14, 23, 37, 60, 97, 156 zadan. Za posebno isticanje broja 153 Petrić je imao mnoge razloge. ${ }^{25}$ Pretpostavljamo da je imao i razloge za posebno isticanje broja $479 .{ }^{26}$

\section{Posebno odabrani sadržaji umješteni u peti i šesti odsječak crte}

Peripatetičke rasprave nisu podijeljene u četiri dijela, kako je to izvana vidljivo, nego na šest dijelova. Unutar trećeg i četvrtog sveska, daljnjom podjelom crte od četvrtog do šestog odsječka, ustrojena su još dva dijela. Osvrnimo se ukratko na sadržaje koji se u tim novim odsječcima nalaze. Počnimo s petim. Sadržaj tog odsječka (FE, 45), kao što već rekosmo, korespondira s temom slaganja iz drugog odsječka i temom neslaganja iz trećeg odsječka. Drugi svezak sadrži osam knjiga slaganja Aristotela s Platonom i drugim starim filozofima, a treći svezak sedam knjiga Aristotelovog neslaganja. Brojeve 8 i 7 Petrić upotrebljava još jedanput i to za sedam Aristotelovih osporavanja Platona i prethodnika i za osam Aristotelovih dokazivanja. Riječ je o Aristotelovu osporavanju Platonova učenja o počelima i o Aristotelovu dokazivanju njegova učenja o istom. Uočimo da se ovdje od Aristotelova slaganja i neslaganja s Platonovom filozofijom i filozofijom starih prelazi na ono ključno u tim filozofijama, na učenje o prvim počelima. S prve razine censure prelazi se na drugu razinu.

Aristotelovih sedam osporavanja učenja o prvim počelima izlaže se na istom mjestu na kojem i Aristotelovo neslaganje s Platonom i prethodnicima, dakle 
u trećem svesku. U istom svesku moglo bi se nastaviti s Aristotelovim dokazivanjima prvih počela, što bi činilo jednu cjelinu. Tada bi treći svezak imao 114 folija, a četvrti 69. Petrić to ne čini, nego taj tekst stavlja u prve tri knjige četvrtog sveska. ${ }^{27}$ Tako tekst od 45 folija stavlja u novi odsječak, koji svojim središnjim položajem, između trećeg i četvrtog odsječka, podjednako pripada jednom i drugom. ${ }^{28}$ To je druga podjela crte, podjela prema natrag $i$ naprijed (prikaz 2, redci 4 i 5).

Petrić izvodi još jednu podjelu crte, podjelu $u$ lijevo $i$ desno (prikaz 2, redci 6 i 9). Podjelom u lijevo, u sredini trećeg odsječka kao većeg (CE, 114), uspostavlja se šesti odsječak GF, a podjelom $u$ desno, u sredini četvrtog odsječka kao većeg $(F B, 114)$, uspostavlja se šesti odsječak EI. U tim i ostalim završnim odsječcima smješteni su sadržaji srodne tematike.

Pogledajmo sadržaj koji se nalazi u šestom odsječku (GF), u šestoj knjizi trećeg sveska. Knjiga nosi naslov: Aristotelova suprotstavljanja Platonu u fiziologiji i njihova rješenja. Ona počinje konstatacijom da je Aristotel više poruga protiv svoga učitelja izložio u prirodnoj filozofiji nego u božanskoj. Zato Petrić odlučuje raspraviti svaku od njih. ${ }^{29}$ Međutim, to nije samo rasprava o prirodnoj filozofiji nego nastavak one o prvim počelima. Dapače, ta rasprava ide i korak dalje od prethodne jer dotiče prva počela s izvora koji su za to učenje mjerodavniji od prethodnih. To su Platonova zagonetna, nepisana učenja o velikom i malom te jednom. ${ }^{30}$ Petrić ih povezuje s Platonovim tezama o

21

Frane Petrić, Peripatetičke rasprave, sv. 2, preveli Tomislav Ćepulić, Mihaela GirardiKaršulin, Institut za filozofiju, Zagreb 2013., str. 299. Dostupno na: https://content.ifzg.hr/ digitalnaBastina/Franciscus_Patricius-Discussionum_peripateticarum_tomus_secundus_Liber_V-VIII.pdf (pristupljeno 29. 06. 2019.).

22

Brojem počinje još samo jedna knjiga, sedma knjiga četvrtog sveska. Tu se naglašeno navodi simbolički i metafizički bremenit broj četiri (tetractys): »Četiri su elementa svijeta (Quattor esse mundi elementa). Događa se to na foliji 437, u čijoj se blizini četvrti svezak dijeli po omjeru krajnjeg i srednjeg (435). Drugim riječima, na tom mjestu završava treća sredina (EI, 24) koja pripada četvrtom odsječku, ako se on uzima kao veći (FB, 114), (prikaz 2, redak 9).

23

U hrvatskom izdanju to nije teško uočiti. Svi su citati veoma pregledno navedeni u bilješkama i mogu se lako prebrojiti. Usp. ibid., str. 259-298.

24

Brojevi drugog niza nastaju, kako smo već rekli, množenjem brojeva prvog niza s brojem 3 .

25

Usp. Ć. Čoh, »Kompozicija 'Nova de universis philosophia' «, str. 241, bilj. 27.
26

Navest ćemo ih u zadnjem poglavlju naše rasprave.

27

To umještanje osporavajućih i dokazujućih teza Petrić precizno naznačuje i u samom tekstu, na početku četvrtog sveska: »Od ovih 15 teza, onih sedam osporavajućih nećemo uopće dotaknuti jer je nešto o njima već raspravljano u onim spisima koji su prethodili. No osam dokazujućih teza ispitat ćemo jednu po jednu.« - F. Petrić, Peripatetičke rasprave, sv. 4, str. 17.

28

U tih 45 folija treba ubrojiti i četvrtu knjigu, premda se u njoj više ne govori o Aristotelovu dokazivanju.

29

Usp. F. Petrić, Peripatetičke rasprave, sv. 3, str. 237.

30

U 13. knjizi prvoga sveska Petrić istinu razgovora (veritas sermonis) smatra višom od istine spisa (veritas scriptorum). Luka Boršić pretpostavlja da Petrić ovdje, na tragu Platonova ezoterijskog učenja, razlikuje »istinu izgovorene riječi« od »istine napisanog teksta«. Usp. Luka Boršić, »Petrićev platonizam u Peripatetičkim raspravama«, u: F. Petrić, Peripatetičke rasprave, sv. 2, str. XI-XX, str. XVII, bilj. 15. 
materiji, prostoru (chora), slijedu dimenzija i smjerovima kretanja, iznijetima uglavnom u Timeju. ${ }^{31}$ Nakon druge razine cenzure uspostavlja se treća.

Aristotelovih poruga odnosno prigovora ima ukupno devet. Prvi Aristotelov prigovor Platonu odnosi se na Platonovo učenje o velikom i malom te jednom (Meth. 987b20-21). Prigovor, kaže Petrić, zapravo nije ni moguć jer se ta počela ne nalaze nigdje u Platonovim knjigama nego su bila izlagana u tajnim razgovorima. ${ }^{32} \mathrm{Ne}$ može se reći ono što kažu Simplicije i Filopon, da se učenje o velikom i malom nalazilo u nenapisanim Platonovim učenjima. Heraklid i Hestijej, koji su zajedno s Aristotelom sudjelovali u Platonovim tajnim razgovorima, posvjedočili su da je ono bilo rečeno u vidu zagonetke. »A ako je to bila zagonetka«, nastavlja Petrić, »Aristotel je prije trebao otkriti smisao zagonetke, zatim, ako ne bi odoljela istini, trebao ju je pobijati «. ${ }^{33}$

O Platonovim tajnim razgovorima u kojima su sudjelovali sam Aristotel, Heraklid, Hestijej i još neki učenici, Aristotel je, kako svjedoče Simplicije i Filopon, napisao knjigu pod naslovom $O$ dobru. Međutim, postoji u fragmentima i knjiga pod naslovom O filozofiji, a Simplicije i Filopon pripisuju ju Aristotelu. No ona može biti, kaže Petrić, samo Platonova. Iz citata koji se iz nje navodi možemo razumjeti zašto Petrić ovdje spominje tu knjigu. Naime, citira jedno mjesto na čijem se kraju govori o slijedu dimenzija:

»... sama doista životinja proizlazi iz ideje jednoga i iz prve duljine i širine i dubine, a drugo pak na sličan način. ${ }^{34}$

Slijed dimenzija jedna je od ideja koje pripadaju sklopu Platonova najvišeg učenja. Petrićeva rasprava u svih devet točaka Aristotelovih poruga ima zadatak upozoriti na taj sklop i ukazati na unutrašnju povezanost njegovih momenata. O slijedu dimenzija bit će opet riječi u odgovoru na treći Aristotelov prigovor.

Premda Petrić kaže da prvi Aristotelov prigovor nije ni moguć, ipak se osvrće na njegovo krivo razumijevanje velikog i malog. Aristotel misli da su to dvije beskonačnosti, a radi se o tome da je beskonačno složeno iz velikog i ma$\log .{ }^{35}$ Petrić opet kaže da Aristotel to nije smio napadati kao neko otvoreno učenje. ${ }^{36}$ Ali postoje učenja, tima srodna, koja su otvorena za napad. Platon je, kaže Petrić, o počelima prirode i otvoreno pisao, misleći pritom na kozmologiju u Timeju. Tamo nije pisao ništa o tom velikom i malom, ali je pisao o nečem drugom i to puno. Naime, pisao je o materiji. To drugo nije nešto posve drugo nego s onim prvim najuže povezano.

Petrić ne prelazi odmah na Aristotelove primjedbe vezane uz Platonovo shvaćanje materije, nego čini jedan međukorak. Navodi problematiku elemenata (vatra, zrak, voda, zemlja) i uređenosti svijeta. Osvrće se na misao koju Aristotel pripisuje Platonu. Naime, da su se elementi, prije nego što je nastao svijet, kretali neuređeno. Petrić na to odgovara da svijet nije nastao iz tog kretanja ni poslije tog kretanja, nego da je stvoren i razlučen od stvoritelja.

Slijedeća, treća Aristotelova primjedba odnosi se na Platonovo shvaćanje materije. Aristotel ne može prihvatiti kako materija, o kojoj govori Platon, nije ništa određeno, nego da je pandeches, ono što sve prima. Petrić pokušava odgovoriti na Aristotelovo pitanje kako može biti da ona nije nijedan od elemenata (vatra, zrak, voda i zemlja), ali je svakomu od njih subjekt, kao što je zlato subjekt zlatnim proizvodima.

Za proširenje rasprave o prvim počelima Petrić ovdje postavlja još jednu temu, onu koju je već započeo u raspravi o prvom prigovoru. Radi se o slijedu dimenzija, ustroju koji ukazuje na odnos točke (ideja jednog), dužine, širine i dubine, odnosno točke, dužine, površine i volumena. Petrić kaže da Aristotel 
u prvoj knjizi $O$ elementima krivo zaključuje, govoreći da Platon misli »da su čvrsta tijela sastavljena od površina, površine iz crta, a ove pak iz točaka« (Cael. 299a6-8). Crta je protežna pa ne može biti sastavljena od točaka jer one nisu protežne. Crta koja je sastavljena od točaka ne može ući u sastav površine, a ta u sastav tijela. Kad bi tijelo bilo sastavljeno od točaka, ne bi imalo težine jer neprotežne točke ne mogu biti ni teške ni lake. Točka nije predočiva nego samo umljiva. Kao ono što prethodi dužini, plohi i tijelu, prisutna je u sve tri dimenzije osjetivog, ali ne kao ono od čega su one sastavljene. Pretpostavljamo da Petrić hoće reći, a to ćemo kasnije i pokazati, kako je točka u dimenzijama osjetivog prisutna kao ono umljivo, a očituje se u dimenzijama umljivog u četvrtom, petom i šestom odsječku crte.

Četvrta Aristotelova primjedba odnosi se na Platonovo shvaćanje vrste mjesta odnosno smjerova u prostoru. Smjerovi su: gore i dolje, naprijed i natrag, desno i lijevo. Platon kaže u Timeju da nije ispravno držati »da po naravi postoje neka dva mjesta, koja dijele sveukupnost u dvoje suprotno « (Tim. 62). ${ }^{37}$ Tako ono kretanje prema gore nije suprotno onom prema dolje, u smislu da bi prvo bilo nasilno, a drugo prirodno. Ne ulazeći u podrobnu raspravu, Petrić najavljuje opširno razmatranje o tome na jednom drugom mjestu. Pritom misli na završnu knjigu čitavog djela koja je smještena u još jednom pojavljivanju šestog odsječka (GB). Time Petrić indirektno upućuje na srodnost tih dvaju mjesta. O tome ćemo govoriti kasnije, a sad se suočimo s mjestom koje nam Petrić otvara središnjom, petom Aristotelovom primjedbom.

\section{Sržno mjesto Peripatetičkih rasprava}

Nakon toga niza od četiri primjedbe, tematski vezanih uz nepisano učenje, Petrić navodi Aristotelovu primjedbu Platonu koja, na prvi pogled, nema nikakve veze s prethodnima. Platon navodi Aristotelovu prosudbu iz druge knjige $O$ nebu da je Platon razmatrao o nastajanju i propadanju, ali da o tome kako nastaju kosti i meso i tomu slično, nije rekao ništa.

»Do sada nitko, osim Demokrita, kaže Aristotel, nije pisao o mijenjanju niti o povećavanju kako su u stvarima, osim o onome što je na površini. « 38

Ta Aristotelova primjedba izazvala je neobično dugo i temeljito Petrićevo pobijanje. Počinje na foliji 342, a završava na foliji $345 .{ }^{39}$ Zar je rasprava o nastanku kostiju i mesa toliko važna? Ili možda Petrić o nastajanju kostiju i

31

Naša pretpostavka o zagonetnom govoru $\mathrm{u}$ ustroju Peripatetičkih rasprava podrazumijeva stav da je Petrić zastupao uvjerenje, koje danas, među ostalima, zastupaju predstavnici Tübingenske škole, a to je da Platon ono bitno svoje filozofije nije iznio u svojim tekstovima. Platon, kaže Petrić, to učenje namjerno nije otkrio jer da ga je otkrio »pokazala bi se potpuno drugačija skrivena misao«. Da je Platon prosudio da ju treba unijeti u svoje knjige, »mislim da bi dobro znao da je sam opiše «. Usp. F. Petrić, Peripatetičke rasprave, sv. 3, str. 241-243. Pretpostavljamo da Petrić glede toga učenja postupa na sličan način.

32

Usp. F. Petrić, Peripatetičke rasprave, sv. 3, str. 239.
33

Ibid.

34

Ibid., str. 241.

35

Usp. ibid., str. 243.

36

Usp. ibid.

37

Ibid., str. 263.

38

Ibid

39

Usp. ibid., str. 263-275. 
mesa govori toliko opširno i toliko temeljito samo zato što se zainatio pokazati kako Aristotel laže kad tvrdi da je o tom problemu nešto govorio samo Demokrit?

Pobijajući Aristotela, Petrić navodi dva teksta iz Platonova Timeja. U tim je tekstovima, kaže on, o kostima i mesu u malo riječi rečeno više nego u svim Aristotelovim knjigama. On prebrojava riječi koje je Platon upotrijebio. Platonov tekst o kostima ima 38 riječi:

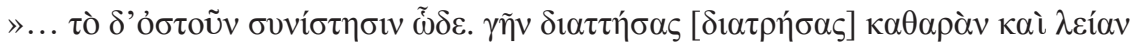

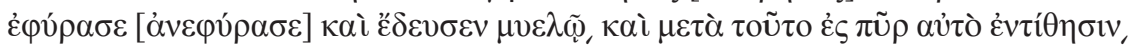

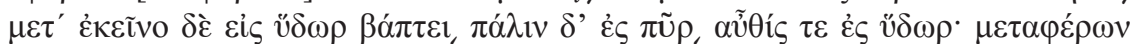

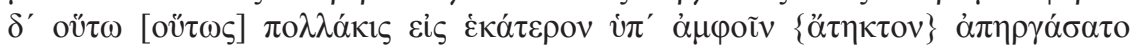

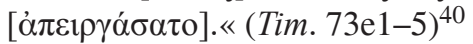

\section{Tekst o mesu ima 23 riječi:}

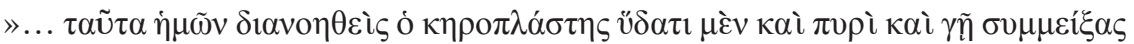

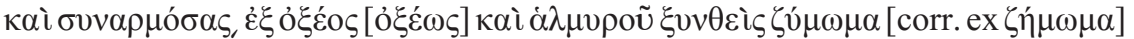

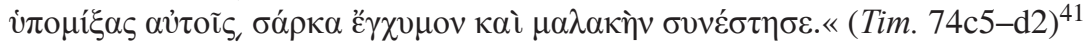

Tekst o kostima ima 15 riječi više od teksta o mesu. Oba teksta sadrže 61 riječ. ${ }^{42}$ Evo nam prvog Petrićevog niza: 1, 7, 8, 15, 23, 38, 61, 99. Ovdje se na posebno snažno naglašen način izriče veza Platonova zagonetnog učenja o velikom i malom te jednom s Petrićevim zagonetnim govorom kroz ustroj Peripatetičkih rasprava. Ali i više od toga. Brojevima 23 i 38 upućuje se na drugu i treću podjelu crte, na onu prema natrag $i$ naprijed te $u$ lijevo $i$ desno. Prevodeći te brojeve prvog Petrićeva niza u drugi Petrićev niz (3, 21, 24, 45, $69,114,183,297,480)$ dobivamo brojeve 69 i 114. Njima su određeni treći i četvrti odsječak na crti, odsječci umljivog (CF, 69 i FB, 114). Kada treći odsječak postaje veći (CE, 114), a četvrti manji $(\mathrm{EB}, 69)$ uspostavlja se središnji odsječak (FE, 45). Konačno, kad se unutar trećeg odsječka kao većeg (CE, 114) diobom izvedenom na sličan način, uspostavi sredina (GF, 24), dolazimo do mjesta u koje je umještena ta rasprava o kostima i mesu. Folija na kojoj ona počinje je folija 342. Petrić se potrudio da taj broj bude na točno, a ne približno određenoj foliji. Tako nam hoće pomoći učiniti ono što nije znao Aristotel, a to je prepoznati i odgonetnuti zagonetku o velikom i malom.

Kao što već rekosmo, nakon teme o kostima i mesu nastavlja se rasprava o Aristotelovim lažima o Platonovoj prirodnoj filozofiji i to opet vezano uz prva počela. Opet je riječ o materiji prihvatiteljici (pandeches), ali sada se ona povezuje s prostorom odnosno umještanjem (chora). U četvrtoj knjizi Fizike Aristotel kaže da su kod Platona materija i prostor (chora) jedno te isto (Ph. 209b.11-16). Kao argument za pobijanje takvog shvaćanja Petrić bogato navodi Platonove tekstove iz Timeja, a jednog od njih (Tim. 48e3-49a6) dijelom je već ranije citirao, neposredno prije diskursa o kostima i mesu. ${ }^{43}$ To je početak drugog dijela Timeja, a ukazuje na potrebu za novim početkom rasprave o počelima. Platon izriče potrebu o potpunijoj podjeli bića od one prethodne. Uz ono umno, tj. uzor koji uvijek jest na isti način i uz odraz uzora koji je vidljiv i nastaje, treba razlučiti treću vrstu, tešku i mračnu. Ona je prihvatiteljica i nekakva njegovateljica svega postajanja (Tim. 49a8-9).

Govorom o toj trećoj vrsti opet dovodimo problematiku prvih počela (veliko i malo te jedno) u vezu s ustrojem cjelokupnosti, odnosno ustrojem filozofskog djela koje o njemu hoće primjereno govoriti. Ta treća vrsta može se povezati s materijom, ali nije materija. Može se povezati s prostorom (topos), ali nije prostor. Može se usporediti sa zemljom, zrakom, vatrom i vodom (Tim. 51a), 
ali nije ništa od toga, »nego nekakva nevidljiva i bezoblična vrsta koja sve prima, a na neki zamršen i teško uhvatljiv način sudjeluje u onom umnom«. Ta treća vrsta jest umještanje (chora) sveukupnosti. Ali isto tako moramo reći, imajući u vidu da je ovdje na djelu i Petrićev zagonetni govor, da se ta treća vrsta može povezati s ustrojem umještanja pojedinih sadržaja Petrićeva djela, s Platonovom crtom podijeljenom omjerom krajnjeg $i$ srednjeg. ${ }^{44}$

Sedma Aristotelova primjedba vezana je uz tematiku duše. Platonu njegov učenik pripisuje učenje da je duša sastavljena od elemenata: vatre, vode, zraka i zemlje. Duša prema Platonu, kaže Petrić, nije sastavljena ni od tih ni od nekih drugih elemenata, nego iz nedjeljivog i djeljivog, istog i drugog. To nisu ni elementi, ni počela, nego bîti (ousiai). Pretpostavljamo da tom primjedbom Petrić implicitno upućuje na jedno bitno svojstvo ustroja svijeta, odnosno filozofskog djela koje ga hoće izlagati. Svijet kao uređeno ustrojstvo jest živ, prožet dušom. Isto tako, živo je i filozofsko djelo. Njegov ustroj, Platonova crta, na što upućuje Petrićev osvrt na središnju Aristotelovu primjedbu, čini ga živim tijelom koje ima meso, kosti i srž. Duša je, isto kao crta, ujedno djeljiva i nedjeljiva, ista sebi i različita od sebe. U njoj je, kao i na crti, umješteno veliko i malo, ali i jedno.

Osma i deveta Aristotelova primjedba, na prvi pogled, vezane su isključivo uz filozofiju prirode. Radi se o vidu i disanju. Međutim, u pozadini obiju tema je već spomenuto kretanje prema gore i dolje, prema naprijed $i$ natrag, u desno i lijevo, odnosno udaljavanja koja podrazumijevaju vraćanja. U vezi vida, Platon pita nastaje li on izlaženjem zraka iz očiju ili zbog ulaska vrsta u oči. Odlučuje se za ovo drugo. Slično tomu, u vezi disanja postavlja pitanje što je prije, udisaj ili izdisaj. Pozivajući se na Platona, tvrdi da izdisaj prethodi udisaju. Sve je to povezano s njegovom koncepcijom kretanja na crti, u kojoj vraćanje prethodi napredovanju.

Tim Petrićevim pobijanjem devet Aristotelovih poruga Platonove filozofije prirode i, prije svega, nepisanog učenja o prvim počelima, ovdje u šestom odsječku, dohvaćena je sama srž censure Aristotelove misli. Tu je ostvaren cilj koji si je Petrić zadao u posljednjoj knjizi prvoga sveska, gdje kaže da mu valja

»... Aristotelovo mišljenje pretresti, ne samo površno ga dotaknuti nego ga potpuno, do same srži [penitus, intimasquae ad medullas] razabrati i zadobiti.«45

40

Usp. ibid., str. 264, bilj. 44.

41

Usp. ibid., str. 266, bilj. 46.

42

Nije posve jasno kojim se kriterijem u prebrojavanju riječi Petrić služio. Međutim, nije važno ima li u tim tekstovima ili nema toliko riječi koliko je navedeno. Važno je upućivanje na brojeve prvog Petrićeva niza.

43

Usp. ibid., str. 249, 275

44

Uspoređivanjem chora s elementima (zemlja, voda, vatra, zrak), Timej nas potiče da nastavimo sa srodnim uspoređivanjem. Uz zemlju, zrak, vatru i vodu vežu se pravilna tijela: heksaedar, oktaedar, tetraedar i iko- saedar pa možemo reći da ta treća vrsta nije ništa od toga, nego takav oblik koji prima sva ta četiri oblika (Tim. 51a1), a na neki zamršen i teško uhvatljiv način sudjeluje i u kugli. Chora nije ni zemlja, ni zrak, ni vatra, ni voda, pa prema tome nije ni heksaedar, ni oktaedar, ni tetraedar, ni ikosaedar. Slijedi jedno dosljedno postavljeno pitanje: a da ona

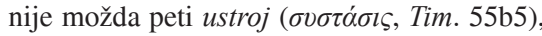
onaj sastavljen po omjeru krajnjeg i srednjeg - dodekaedar (Tim. 55c7-9)? Usp. Ćiril Čoh, »Matematika i mišljenje svrhe sveg mislivog u Platona«, Filozofska istraživanja 37 (2017) 4, str. 797-812, str. 807-808, doi: https://doi. org/10.21464/fi37412.

45

F. Patricius, Discussiones Peripateticae, str. 163. 


\section{Pokazivanje jednog kao malog koje je veliko i kao velikog koje je malo}

Način na koji Petrić prezentira Platonovu crtu govori da o njoj posjeduje jedno znanje koje je puno dalekosežnije, šire, dublje i potpunije od onog koje imaju u vidu interpreti šeste i sedme knjige Platonove Politeje. U interpretaciji Platonove crte interpreti uglavnom polaze od pretpostavke da je to jedna od triju usporedbi kojima se Platon pokušava približiti određenju dobrog. I njima je crta zagonetna, ali to je zagonetnost suprotna onoj koju vidi Petrić - to je zagonetnost čije se ustrojstvo ne prepoznaje. Zato, pokušavajući ju riješiti, postavljaju posve kriva pitanja. Prvo je pitanje treba li crtu postaviti vodoravno ili okomito, odnosno pokazuje li se na njoj kretanje prema gore ili prema naprijed. Drugo je pitanje hoće li se odsječci na crti postavljati od većih prema manjima ili od manjih prema većima. Neki interpreti još postavljaju pitanje o omjeru kojim treba dijeliti crtu odnosno njene odsječke.

Odgovor na prvo (krivo) pitanje ovisi o tome treba li interpretu crta predstavljati neki izlazak iz ponora prema gore ili pak neko napredovanje, u smislu udaljavanja od početne do završne pozicije. Drugo pitanje vezano je za određenje značenja većeg i manjeg. Umljivo u sebi ima više bitka nego osjetivo pa je pitanje pripada li mu zbog toga veći ili manji dio crte. Treba li osjetivo prema umljivom prikazati odnosom većeg dijela prema manjem ili manjeg prema većem?

Treće pitanje, ono o omjeru kojim se dijele crta i njeni odsječci, postavljaju samo neki interpreti. Uvjereni su da u njenoj interpretaciji mora doći do izražaja ne samo simboličko značenje većeg i manjeg nego i simboličko značenje omjera. Međutim, ako je crta samo jedna od usporedbi, neki posebni omjer ne dolazi do izražaja. Svaka je podjela, koja zadovoljava osnovni uvjet, prihvatljiva. Taj je uvjet da se crta dijeli na veći i manji dio, a potom svaki od njih po istom omjeru. Postoji mnogo mogućnosti takve podjele i nijedna, s takvog stanovišta, nema prednost pred drugom. Pokušalo se dati prednost omjeru krajnjeg $i$ srednjeg, ali s argumentima, koji zbog polazne teze o crti kao usporedbi, nemaju gotovo nikakvu težinu. ${ }^{46}$

Petrić u kompoziciji Peripatetičkih rasprava ima sasvim drugačije shvaćanje pitanja o crti. Irelevantna su mu posve prva dva, a relevantnost vidi tek u trećem. Crta se može postaviti bilo okomito bilo vodoravno jer ona nije u funkciji slikovnog izraza. Njenim položajem ne postiže se nikakva misao. On crtu ne shvaća kao usporedbu, sliku kojom se izriče teško izreciva, a možda i neizreciva misao. On kroz nju misli. A ono što kroz nju misli (misli, a ne predočuje) upravo su ono gore $i$ dolje, naprijed $i$ natrag i lijevo i desno u tri dimenzije osjetivog i u tri dimenzije umljivog. Nadalje, pitanje o poretku odsječaka Petriću je također irelevantno. To je stoga jer se na crti ne misli samo kretanje u smjeru napredovanja nego i u smjeru vraćanja. Napredovanje mora u sebi nositi vraćanje. Ono to može, ako je uspostavljen adekvatan omjer. Tada duži odsječak uspostavljen u smjeru napredovanja postaje kraći, a kraći postaje duži. Svaki od dijelova pokazuje se i kao veći i kao manji. Postoji samo jedan omjer koji na crti izražava napredovanje koje pretpostavlja vraćanje, u kojem veće postaje manje, a manje postaje veće. To je upravo onaj omjer koji je Petrić ugradio u kompoziciju Peripatetičkih rasprava.

Potrebno je razlikovati crtu kao jednodimenzionalnu odredbu od Platonove crte odnosno crte. Platonova crta kao usporedba jest jednodimenzionalna odredba, jedna od triju dimenzija u prostoru. S druge strane, na crti koja nije usporedba, misle se sve tri dimenzije osjetivog: duljina, širina i dubina te tri dimenzije umljivog. Na njoj se pokazuju tri kretanja u smjeru napredovanja 
i tri kretanja u smjeru vraćanja. Ona su međusobno ovisna: nema kretanja prema gore bez kretanja prema dolje, kretanja naprijed bez kretanja natrag ni kretanja $u$ desno bez kretanja $u$ lijevo. Nadalje, u svakom od njih ono u smjeru vraćanja prethodi onom u smjeru udaljavanja.

Kretanje prema dolje, dakle vraćanje, prethodi kretanju prema gore, napredovanju. ${ }^{47}$ Nekako po prirodi stvari za očekivati je da kretanje prema gore prethodi kretanju prema dolje. Dolje bi trebala biti početna točka, a gore cilj. To je istina, ali ne kad je riječ o kretanju na crti - i to ne samo kod Petrića nego i kod Platona. Vidljivo je to u alegoriji spilje. Platonov prikaz situacije zatočenika u spilji upućuje na to da oni iz spilje ne mogu izići, ako ih ne vodi netko tko je došao odozgo. Da bi izišli, oni bi trebali svoje kretanje započeti istinski odnosno dobro, a to ne mogu jer još ne poznaju dobro. Dobro započeti znači, a tu ćemo odredbu naći i kod Platona ${ }^{48}$ i kod Petrića ${ }^{49}$ tako započeti da smo prešli više od polovice puta i osigurali završetak putovanja.

Ako ne možemo dobro započeti, započinjemo sa sviješću da se još nismo uzdigli do počela, do dobra, strože rečeno, do velikog i malog te jednog. Učinili smo zalet prema njemu, a morat ćemo ga ponavljati sve dok se do njega ne uzdignemo. Tako rade dijalektičari. Dosegnuvši počelo, nakon mnogih zaleta, mogu se bez zalijetanja podizati prema gore i spuštati se prema dolje. Međutim, to počelo nije postavljeno negdje gore, u jednom od odsječaka crte, u onom četvrtom po redu, kako to interpreti najčešće misle. A nije ni u petom ni u šestom. Ono je uspostavljeno u istinskom napredovanju koje pretpostavlja vraćanje, napredovanju i vraćanju u kojem veće postaje manje, a manje postaje veće, veliko postaje malo, a malo veliko, da bi se uspostavilo jedno.

Dužina trećeg sveska Peripatetičkih rasprava nije samo 69 nego i 114. Isto tako, dužina četvrtog sveska nije samo 114 nego i 69. To je stoga što je u istinskom napredovanju i s njim povezanom vraćanju manji odsječak crte postao veći, a veći manji. Svaki od odsječaka jednak je sebi, ali je ujedno i veći i manji od sebe. Isto tako, on je i veći i manji od onog drugog koji je s njim postavljen u odnos. ${ }^{50}$ Tim uvidom došli smo u blizinu izlaganja $\mathrm{o}$

46

Tezu o potrebi rezanja Platonove crte po omjeru krajnjeg $i$ srednjeg među ostalima zastupaju: Gregory Des Jardins, »How to Divide the Divided Line«, The Review of Metaphysics 29 (1976) 3, str. 483-496; John Paul Dreher, »The Driving Ratio in Plato's Divided Line «, Ancient Philosophy 10 (1990) 2, str. 159-172. Kritiku te teze daje: Yuri Balashov, »Should Plato's Line be Divided in the Mean and Extreme Ratio?«, Ancient Philosophy 14 (1994) 2, str. 283-295, doi: https://doi. org/10.5840/ancientphil19941423. Diskusiju prihvaća i: Kenneth M. Sayre, Plato's Late Ontology: A Riddle Resolved, Princeton University Press, Princeton 1983., str. 304. On tako tvrdi: »Moguće je (ali jedva) da je Platon u konstrukciji podijeljene crte imao na umu zlatni rez (ili zlatni pravokutnik) i misao o njegovim jedinstvenim estetskim kvalitetama koje na neki način reflektiraju Dobro kao ideal ljepote.« Prednost pred drugim omjerima mogao bi imati i onaj koji je vezan za slijed dimenzija ( $\left.\mathrm{a}, \mathrm{a}^{2}, \mathrm{a}^{3}, \mathrm{a}^{4}\right)$, npr. omjer $1: 3$ gdje se unutar osjetivog postavlja $9: 27$, a unutar umljivog 27 : 81 . Njime bi se ukazivalo na odnos površine spram volumena unutar osjetivog i na odnos volumena spram neke više dimenzije koja nadilazi osjetivo unutar umljivog, za što bi se moglo naći opravdanje $u$ Platonovom tekstu. O tome više u slijedećem poglavlju.

47

Isto tako, kretanju prema naprijed prethodi kretanje prema natrag, a kretanju $u$ desno kretanje $u$ lijevo.

48

Primjerice: »No početak je, kako se meni čini, više od polovice $\mathrm{i}$ ako on pođe za rukom, nitko ne može to riječima dovoljno pohvaliti.« - Leg. 753e.

49

Primjerice: »Čini se, dakle, da je samo počelo više od polovice cjeline. «-F. Petrić, Peripatetičke rasprave, sv. 4, str. 41.

50

To isto se dalje događa kroz već pokazanu uspostavu zadnjeg odnosno šestog odsječka. 
jednom u Platonovom dijalogu Parmenid. U njemu se u prva dva ispitivanja pretpostavke »ako jedno jest što onda slijedi za jedno i za druga«, raspravlja o manjem i većem.

U prvom ispitivanju (Parm. 137c4-142a8) spomenute pretpostavke ispituje se: »ako jedno jest, što slijedi za jedno, ako je samo jedno, ako ne sudjeluje u jestvu«. Za njega se kaže da

»... nikad neće biti jednako, kako se čini, ni sebi samome ni drugome; te opet ni veće a ni manje, ni od samoga sebe, ni od drugoga.«(Parm. 140d6-8)

$\mathrm{U}$ drugom ispitivanju iste pretpostavke (Parm. 142b-155e3) ispituje se: »ako jedno jest, što slijedi za jedno, ako treba biti, tj. ako je ono jedno koje jest «. Za njega se kaže:

»Ono jedno je dakle sámo i jednako i veće i manje, i od sebe samoga i od onih drugih.« (Parm. $151 \mathrm{~b} 5-\mathrm{c} 7)^{51}$

Upućuje li Platon ovdje na crtu, na njenu podjelu po omjeru krajnjeg $i$ srednjeg, na izričaj počela velikog i malog te jednog, koji ona omogućuje? To pitanje dobiva na težini ako imamo u vidu još jednu činjenicu. Naime, prema stihometrijskoj analizi Jaya B. Kennedyja, ${ }^{52}$ ta rečenica iz drugog ispitivanja postavljene pretpostavke (Parm. 151b5-c7) nalazi se na mjestu na kojem je tekst Parmenida razdijeljen po krajnjem i srednjem omjeru. Do ovog mjesta sadržano je $61,8 \%$ teksta, a $38,1 \%$ nakon tog mjesta. ${ }^{53}$

Problematika crte kod Petrića nije prisutna samo u njegovom zagonetnom govoru kroz ustrojstvo Peripatetičkih rasprava. On o njoj i izričito govori u četvrtoj knjizi trećeg sveska. ${ }^{54}$ Tu razmatra odnos matematičke i dijalektičke analize postavljen u odsječku umljivog. U obje se analize događa napredovanje i vraćanje, s time da se u matematičkoj događa vraćanje na poziciju s koje se i krenulo pa kretanja odnosno obrata zapravo i nema. Istinski obrat, onaj o kojem smo gore govorili, događa se samo u dijalektičkoj analizi.

\section{Povezanost načela velikog i malog te jednog s dimenzijama prostora i smjerovima kretanja}

Na samom kraju Peripatetičkih rasprava, u zadnjoj knjizi četvrtog sveska, Petrić stavlja već najavljenu, ${ }^{55}$ opširnu raspravu o šest smjerova kretanja i s njima povezanim dimenzijama prostora. Čudan završetak Petrićeva djela! Ali ta rasprava najavljena je u samoj srži djela, u šestom odsječku GF, a spomenuto je mjesto njenog opširnijeg izvoda također određeno šestim odsječkom (HB, 24). Tim umještanjem ona dobiva novi smisao. Ona se tu izvodi ne samo zbog pobijanja Aristotelovog krivog shvaćanja dimenzija i smjerova u prostoru nego i zbog upućivanja na zagonetni govor o prvim počelima: velikom i malom te jednom. Vidjeli smo da Petrić tih šest smjerova ne prepoznaje samo u dimenzijama osjetilnog nego i na crti gdje se one, u cjelini koju čine s dimenzijama umljivog, ne predočuju nego misle..$^{56}$

Dimenzije osjetivog se na crti misle jer ta crta, kao što smo već rekli, nije jednodimenzionalna odredba, jedna od triju dimenzija prostora. Na njoj se misli jednodimenzionalnost odnosno duljina, ali i površina i volumen. Površina se u odnosu na duljinu misli kao dužina duljine koja je podignuta na drugu potenciju. Volumen se misli kao dužina duljine koja je podignuta na treću potenciju. Daljnje potencije dužine duljine izražavaju dimenzije umljivog. Prva dimenzija umljivog izriče se četvrtom, druga petom, a treća šestom potencijom dužine određene duljine. Prikazano na crti izvedenoj u ustroju Peripatetičkih 
rasprava to izgleda ovako: dužina crte je 480; dimenzija duljine nalazi se u dužem dijelu, u odsječku osjetivog, a iznosi 297; dimenzija površine je u kraćem dijelu, u odsječku umljivog, i iznosi 183; kraći dio u odsječku osjetivog i duži dio u odsječku umljivog imaju istu dužinu, 114, a njome se izražava treća dimenzija osjetivog; prva dimenzija umljivog izražena je u dužini 69 , druga u dužini 45 , a treća u dužini $24 .{ }^{57}$

Povezivanje odnosa između različitih područja bića prikazanih na crti s dimenzijama osjetivog i umljivog nije Petrićeva novina. Nailazimo na to i kod Platona u šestoj i sedmoj knjizi Politeje. Platon navodi da se u drugom odsječku osjetivog nalaze trodimenzionalna, osjetiva bića, a u prvom odsječku njihova dvodimenzionalna odredba, slika. ${ }^{58}$ Nadalje, u prvom odsječku umljivog nalaze se geometrijski objekti u sve tri dimenzije osjetivog, postavljeni u odnos s umljivim. Tri dimenzije osjetivog, pošto su posredovane kroz geometriju, ovdje se i predočuju i misle. U drugom odsječku umljivog uspostavljena je dimenzija koja je viša od dimenzija osjetivog pa se više ne može predočiti nego samo misliti, naravno ako je određenim omjerom takav prikaz omogućen.

U devetoj knjizi Politeje možemo, u jednoj brojevnoj zagonetci, prepoznati upućivanje na niz od sedam brojeva: $1,3,9,27,81,243,729$. To je niz u

51

Postajanje velikoga malim, a maloga velikim $\mathrm{u}$ drugom preispitivanju spomenute pretpostavke u Parmenidu razmatra i Petrić. Navodi slično mjesto u blizini Parm. 151b5-c7. To je Parm. 150a3-6. Od značaja je da je to razmatranje smjestio u jednom od četiri odsječaka od 24 folije, u onom u samom središtu djela (JK). Usp. F. Petrić, Peripatetičke rasprave, sv. 2 , str. 359 .

52

John B. Kennedy, »Plato's Forms, Pythagorean Mathematics, and Stichometry«, Apeiron 43 (2010) 1, str. 1-32, str. 23, doi: https://doi. org/10.1515/APEIRON.2010.43.1.1.

53

Izgleda da se Platon služi sličnim zagonetnim govorom kojim se služi i Petrić. Svoja djela reže po omjeru krajnjeg $i$ srednjeg da bi na mjestu toga reza ostavio njegov trag. Vrhunac je toga razdioba Politeje. Ona se dijeli po krajnjem i srednjem omjeru upravo na mjestu gdje počinje govor o crti. Podjelom Politeje po omjeru 61,8 / 38,1 dolazimo do mjesta Resp. 508c9. Devet redaka ispred $(61,7 / 38,2)$ Sokrat kaže da je dobro samo sebi srazmjerno (Resp. 508b13), što je početak drugog dijela rasprave o poredbi sa Suncem, da bi se uskoro nakon toga progovorilo o razdiobi crte (Resp. 509d6). Usp. ibid., str. 22

54

Usp. F. Petrić, Peripatetičke rasprave, sv. 3, str. 157-161. Mihaela Girardi-Karšulin smatra Petrićevu interpretaciju crte u mnogo čemu iznenađujućom. Usp. Mihaela GirardiKaršulin, »Petrićevo tumačenje Platonove usporedbe s crtom«, u: Filip Grgić (ur.), Godiš- njak za filozofiju, Institut za filozofiju, Zagreb 2004., str. 107-135, str. 145.

55

Vidi završetak III. poglavlja.

56

Kretanje u šest smjerova u prostoru predočujemo kroz tri dimenzije osjetivog, a kretanje u šest smjerova na crti jest misao o tri dimenzije osjetivog koje su postavljene u odnos s isto toliko dimenzija umljivog. Tih šest dimenzija su dimenzije cjeline unutar koje je postavljen odnos osjetivog i umljivog.

57

Treba imati u vidu da su to približne vrijednosti. Točna vrijednost određena je omjerom krajnjeg $i$ srednjeg. Ona je u prikazu (prikaz 2) naznačena pored svakog broja iz drugog Petrićeva niza. Broj $\phi$ ima vrijednost $1,6180339 \ldots$

58

Vidljivo je to i u odnosu dužina, ako se odabere odnos vezan uz slijed dimenzija (vidi bilješku 45). Ako je npr. omjer 1:3, onda se na crti uspostavljaju dužine 9, 27, 27 i 81, odnosno $3^{2}, 3^{3}, 3^{3}$ i $3^{4}$. Međutim, taj omjer ne omogućuje uspostavu pete $\mathrm{i}$ šeste potencije duljine. One se na crti ne mogu izvesti. Zbog toga na crti izvedenoj po tom omjeru ne može doći do prikaza okreta velikog u malo i malog u veliko, do očitovanja jednog. Na njoj se može pokazati samo okret trećeg odsječka (CE) u drugi (DC), jednakog u jednako. Zato je taj omjer primjeren za prikaz dosega matematike u odnosu na doseg dijalektike, za »okretanje crijepa«, u odnosu na »okret iz noćnog nekog dana u istinski«(Resp. 521c6). 
kojem je treći član (9) druga potencija drugog člana (3), četvrti (27) treća potencija drugog, peti (81) četvrta potencija drugog, šesti (243) peta potencija drugog i sedmi (729) šesta potencija drugog. On se može usporediti s brojevima drugog Petrićeva niza koji se pojavljuju na crti: 24, 45, 69, 114, 183, 297 , 480. Ti se brojevi odnose na poredak zadovoljstava od najnižeg do najvišeg (Resp. 587c-e). Govor nije izričit nego, kako bi rekao Petrić, zagonetan.

Postoje dobri razlozi u prilog tezi da Platon u devetoj knjizi razvija dalje ideju crte iz šeste i sedme knjige na način na koji to čini Petrić u Peripatetičkim raspravama. Puno toga u brojevnim odnosima u devetoj knjizi Politeje upućuje na odnose na crti koji su postavljeni u šestoj i sedmoj knjizi. Prije svega, odnos osjetivog i umljivog analogan je odnosu osjetilnog uživanja i duhovnog uživanja. U prilog tomu govore i Kennedyjeva stihometrijska istraživanja. On navodi čak pet dijaloga koji se dijele po omjeru krajnjeg $i$ srednjeg upravo na mjestu gdje se problematizira taj ili njemu sličan odnos. ${ }^{59}$

Platon zadovoljstva dijeli na istinska, lažna i na ona koja to nisu. Jedna imaju u sebi više, druga manje bitka. Zadovoljstvo koje je najbliže onom najvišem i najčišćem pripada kralju vladaru. Najudaljenije od najvišeg zadovoljstva je zadovoljstvo tiranina. Između toga su zadovoljstva aristokrata, oligarha i demokratskog čovjeka. Zadovoljstvo kralja odnosi se prema zadovoljstvu oligarha kao što se zadovoljstvo oligarha odnosi prema zadovoljstvu tiranina. Zadovoljstvo kralja je 729 puta veće od zadovoljstva tiranina. Postavljeni odnosi između zadovoljstava podsjećaju na odnose između područja bivanja i moći spoznavanja prikazanim na crti. Razlika je u tome što tih odsječaka ovdje ima više jer se podjela nastavlja i nakon uspostave onog četvrtog.

Platonu se zamjera da tu pokušava kvantitativno izraziti koliko je netko zadovoljniji od drugoga. Posebno mu se predbacuje da kroz brojevni odnos uspoređuje tjelesna zadovoljstva, koja zapravo i nisu prava zadovoljstva, s onim duhovnim. Međutim, sve te primjedbe postaju bezrazložne, ako se uzme u obzir mogućnost da Platon tim odnosima upućuje na odnose unutar crte, i to podijeljene do šestog odsječka. ${ }^{60}$

Platon daje naznaku za još jedno tumačenje broja 729, a vezano je vjerojatno uz Filolajevu podjelu godine na 364,5 dana i 364,5 noći (Resp. 588a). Izgleda da Petrić ima u vidu to tumačenje i da ga koristi da bi skrenuo pozornost na povezanost Platonove crte s nizom potencija koji završava brojem 729 u devetoj knjizi Politeje. Zbog toga svoje djelo ne završava s folijom 480 nego s folijom 479. Naime, ako broj folija zadnjeg sveska (114) odbijemo od broja 480 , dolazimo do broja 366 . Tim bi brojem bila označena prva folija tog sveska kad bi djelo imalo 480 folija. No budući da djelo ima 479 folija ta prva folija je ona s brojem 355. Tako se dolazi, najbliže što je to moguće, do Filolajeva broja noći, odnosno, dana u godini, do broja 364,5. Postavljen na kraju trećeg sveska $(\mathrm{CF}, 69)$ i na početku četvrtog $(\mathrm{FB}, 114)$, postavljen u točci gdje je četvrti odsječak okrenut u treći, a treći u četvrti, taj broj ukazuje na okret u kojem se iz neke noći ulazi u istinski dan.

\section{Zaključak}

Ustroj Petrićevih Peripatetičkih rasprava nema samo estetsku ili neku tomu sličnu funkciju. Prije svega, to je ustroj kroz koji je izrečeno jedno učenje. To nije bilo koje učenje, nego ono od svih najveće - megiston mathema (Resp. 505a) - o počelima svega, o dobrom, o velikom i malom te jednom. Njegova se priroda može adekvatno izreći samo kroz zagonetku. Zato Petrić optužuje 
Aristotela što o tom učenju govori kao da je negdje zapisano, umjesto da se adekvatno postavi spram zagonetke, da je prepozna i odgonetne. Petrićev zagonetni govor upravo je jedno takvo postavljanje spram Platonova nepisanog učenja. Postavio ga je u zagonetki i to tako da ta zagonetka bude prepoznatljiva i odgonetljiva.

Zagonetka ustroja Peripatetičkih rasprava je zagonetka umještanja, zagonetka onog što Platon zove chora. Ona svemu što jest daje njegovo vlastito mjesto, ali isto tako ona ustrojava filozofsko djelo, ako se to sve što jest izlaže u svjetlu prvih počela. Slično vrijedi i za filozofsko djelo koje hoće biti censura nečije filozofije, ovdje konkretno Aristotelove. Petrić u trinaestoj, zadnjoj knjizi prvog sveska, kaže da u svescima koji slijede »Aristotela, odnosno njegovo mišljenje treba pretresti, ne lagano ga dotaknuti, nego ga treba potpuno, do same srži (ad intimas medullas) razabrati i zadobiti«. Pod Aristotelovim se mišljenjem ovdje ne podrazumijeva samo Aristotelova filozofija u cjelini. To je tek prva razina cenzure. Dublja censura dohvaća Aristotelovo mišljenje o ispravnoj metodi filozofiranja koja nas dovodi do istine o nekoj filozofiji ili pak do istine samih stvari i bića o kojima netko filozofira. Kao što treba filozofirati o nekoj stvari iz same stvari, tako i o Aristotelu treba filozofirati iz samog Aristotela. Kao što u istinskoj filozofiji u svjetlu istine prvih počela stvar sebe samu pokazuje, tako će i ovdje u tom istom svjetlu do same srži pokazati sebe i Aristotel.

Peripatetičke rasprave imaju ustroj kojim se uspostavlja njihova sredina, ali takva koja prodire u sve dijelove. Postoje, zapravo tri međusobno povezane sredine. Prva sredina je sredina čitavog djela. U nju pada sadržaj drugog sveska. Sadržaj prvog sveska pada u jedan, a sadržaj trećeg i četvrtog sveska u drugi kraj. Krajevi su jednake dužine. Međutim, nije svaka sredina prava sredina. Nije dovoljno da bude smještena između dva kraja i da ti krajevi budu iste dužine. Potrebno je da prva sredina može ući u svaki od krajeva i da unutar njih formira novu sredinu istih svojstava, sve do one zadnje, sržne, prisutne u svim dijelovima cjeline. To se može dogoditi ako se cjelina dijeli po omjeru krajnjeg $i$ srednjeg.

Peripatetičke rasprave ustrojene su prema Platonovoj crti. Za Petrića ona je mjesto (chora) koje omogućuje da se pokažu prva počela. Na njoj je vidljivo kako je malo veliko, a veliko malo. Tako ona pokazuje jedno. Na njoj vraćanje prethodi udaljavanju, a kretanje počinje tako da se tim početkom prelazi sredina i osigurava kraj. Njezin ustroj srodan je slijedu dimenzija, gdje se tri dimenzije umnog, smještene u početku, u točki, pokazuju tek iza triju dimen-

59

Tako se dijalog Fileb dijeli po omjeru krajnjeg $i$ srednjeg kod rečenice: »Očito najveće naslade, a tako i neugode, nastaju u nekoj iskvarenosti duše i tijela, a ne u vrlini.« (Phileb. 45e7) Tri retka prije toga spominje se čuvena Bijantova izreka: »Ništa odviše.« U Timeju se na mjestu te podjele pod $65 \mathrm{~b} 7$ razlaže fiziološka teorija zadovoljstva i boli. U Charmidu, umjesto spomenute podjele je pod 167e1-e2, kod rečenice: »Ali čini ti se da postoji neka žudnja ni za kojim uživanjem, nego za samom sobom i drugim žudnjama.« Nekoliko redaka nakon toga $(168 \mathrm{~b} 10-\mathrm{c} 2)$ to se povezuje s izričajem o većem i manjem, sličnom onom iz Parmenida (151b5-c7). Dijalog Kratil reže se po krajnjem i srednjem omjeru pod brojem 419d7. Tu se objašnjava etimologija riječi umjerenost (euphrosynēe $\mathrm{u}$ istom sklopu s objašnjenjima riječi: zadovoljstvo, bol, želja i eros (419b5-420b5). Dijalog Zakoni po našem se omjeru dijele na $840 \mathrm{~d} 8$. Tu je riječ o savladavanju kojim se postiže najdivnija pobjeda, pobjeda koja dovodi do najviše sreće, naime pobjeda nad uživanjima. Usp. John B. Kennedy, The Musical Structure of Plato's Dialogues, Acumen Publishing, Durham 2011., str. 240-241.

60

Ako je to tako, onda ovdje Platon upućuje i na to da na crti ne može biti postavljen bilo koji omjer pa ni bilo koji od onih koji pripadaju slijedu dimenzija (npr. 1:3), nego samo omjer krajnjeg $i$ srednjeg. 
zija osjetivog: dužine, površine i tijela. Živ je to ustroj pa se u samoj srži djela dovodi u vezu s ustrojem ljudskog bića. Na tom mjestu Petrić navodi Platonove tekstove o postanku kostiju i mesa. Ta dva teksta sastavljena od šezdeset i jedne riječi rječitija su od trideset i dvije Aristotelove knjige. U njihovom je odnosu određen omjer koji omogućuje prevladavanje krajnosti kroz uspostavu triju sredina, sve do one sržne, a u opisu nastanka kostiju pratimo genezu ustroja Peripatetičkih rasprava. Platon kaže da je »stvoritelj uzeo najfiniju zemlju i pomiješao je sa srži. Tu mješavinu je najprije stavio u vodu, a nakon toga u vatru«, dakle premještao ju je iz jedne krajnosti u drugu. »Ponovio je to još nekoliko puta da toj mješavini nijedna od krajnosti, ni vatra ni voda više ne bi mogla naškoditi«. Srž ulazi u kosti, a da bi bila još sigurnija, kosti se obavijaju i skrivaju mesom.

\title{
Ćiril Čoh
}

\section{Patricius's Enigmatic Delivery through the Structure of Peripatetic Discussions}

\begin{abstract}
This paper is based on the assumption that, in Patricius's philosophy, the totality is analogous to the philosophy of the totality (philosophia universi), that is, to the work that delivers it. Everything that arises in the totality has its emplacement, its chora. Likewise, everything that is provided in the philosophical work must be given in its place. With the number of its parts and the mutual relations between these parts, Patricius's work Peripatetic Discussions shows us that the work is very carefully structured. The number of volumes, the books and folios within each of them is not incidental. All of this points to the structure of the work according to Plato's line. The purpose of the work is the assessment (censura) of Aristotle's philosophy in opposition to true philosophy, that is, philosophy of Plato and his predecessors, their doctrines on the first principles and above all, of Plato's unwritten doctrine of the Great and Small, and the One. How true philosophers are delivering these doctrines cannot always be direct; rather, it must be enigmatic in what is substantial.
\end{abstract}

\section{Key words}

Franciscus Patricius, Peripatetic Discussions, agrapha dogmata, Plato's line, Plato, Aristotle, delivery, Great and Small, matter, emplacement, chora 